\title{
Comparison the Application of PBL (Project Based Learning) and PBL (Problem Based Learning) Learning Model on Online Marketing Subjects
}

\author{
Agnes Dini Mardani \\ Titis Shinta Dhewi \\ Ludiwishnu Wardana \\ Program Studi Pendidikan Tata Niaga Universitas Negeri Malang \\ E-mail: titis.shinta.dhewi.fe@um.ac.id
}

\begin{abstract}
Purpose of this study are (1) the application of learning PjBL with PBL to improve study results students, (2) assessing the domain affective, cognitive, and psychomotor, (3) the difference study results use the PjBL with PBL to improve study results students. The research is research quantitative and including research apparent experiment (quasi eksperiment) by taking sample class two classes X PM 1 as a class experiment and class X PM 2 as a class control. Research instruments used for data collection namely: (1) tests to pretes and postest used to determine the cognitive assessment, (2) sheets observation affective, (3) sheets of the process for the psychomotor. The trial research instruments use the validity and reabilitas. Analysis techniques data using: (1) test a prerequisite analysis consisting of normality test and the homogeneity (2) T test unpaired which ended with the help of computer programs spss. Based on the result of this research can be concluded that: (1) the application of PjBL (Project Based Learning) and PBL (Problem Based Learning) should be conducted well in accordance syntax learning, (2) assessing the cognitive students have a difference and class experiment having an average higher than class control, (3) assessing the results affective students have a difference and on the application of PjBL is better than PBL.
\end{abstract}

Keywords: Learning Strategy, Learning outcomes

Education development aims is to develop the qualified human resources to compete in a business world. Seeing the role of education is so important well as the rapid development of technology for competitive competition. The role of teachers is very important in the learning process, although it is not dominating but guiding and directing students actively obtain information and construct own knowledge obtained, and do the variations in the learning process, so the students are more challenged to learn in order to achieve the learning activities.

Learning process determines the successful learning activities are performed by students. Learning activities are the main activities determining the success or failure of educational attainment goals. To achieve this goal, teachers must find appropriate learning strategies to apply in the classroom environment and be able 
to encourage students to be active in the classroom and achieve successful learning outcomes. During this time there are many subjects taught by teachers using conventional models so less effective in achieving learning outcomes and one of them is the subject of Online Marketing.

Online Marketing subjects are local content that was applied only a few years ago and still many in its application using conventional method so that in student learning process less attention and result of study not yet complete. From these conditions, the researcher tries to apply new learning model that is Project Based Learning (PJBL) and Problem Based Learning (PBL) which is expected by students to have innovative learning process (Blandul, 2015) with complete result. Implementation of these two learning models aims to improve student learning outcomes and can know the difference in learning results on online marketing subjects by using the model of learning PjBL and PBL. Both of models have learning indicators not only through lectures but problem solving and application to practice them (Chan, 2017).

Jhonson et al (2013:560) in his journal entitled "Project Based Learning and Student Engagement", concludes that "I decided to implement PBL in my own classroom and study its effects on students' behavioral, cognitive, and emotional engagement. I decided to apply my class PBL and study the effects of emotional cognitive engagement and behavior not only on behavior but also on their learning outcomes".

This is also explained by Ajai et al (2013: 131) that the discovery of this study is the use of strategy PBL is a good way for students to learn math rather than using conventional methods. Online math and online marketing have indicators that are not much different that can not only be explained but also require implementation in order to have good results.

Based on the above explanation, the hypothesis of this study follows:

$\mathrm{H}_{0}: \mu_{1}=\mu_{2}$, There is no difference in learning outcome by using model PjBL (Project Based Learning) rather than learning model PBL (Problem Based Learning).

$\mathrm{H}_{1} \neq \mu_{2}: \mu$, There is a difference in the increase of learning outcomes by using the learning model of PjBL (Project Based Learning) rather than using the PBL (Problem Based Learning) model.

\section{METHOD}

This study examines the cognitive, affective, and psychomotor aspects of the students by using two models of learning. Learning model used based on learning and project based learning model. The research used quasi experiment method, because the treatment will given on the subject of the study is not fully controlled by the researcher. The research design of quasi experiment is one of pretest-posttest non equivalent control group design (Sugiyono, 2012: 116).

Table 1. Research design pretest-posttest control group design (quasi experiment)

\begin{tabular}{llll} 
Group & initial tests & Treatment & the final test \\
\hline Experiment & $\mathrm{O}_{1}$ & $\mathrm{X}_{1}$ & $\mathrm{O}_{3}$ \\
Control & $\mathrm{O}_{2}$ & $\mathrm{X}_{2}$ & $\mathrm{O}_{4}$ \\
\hline
\end{tabular}


Information:

$\mathrm{X}_{1} \quad$ : Model of Learning PjBL (Project Based Learning)

$\mathrm{X}_{2}$ : The learning model PBL (Problem Based Learning)

$\mathrm{O}_{1} \quad$ : Pretest for the experimental class

$\mathrm{O}_{2}$ : Pretest for grade control

$\mathrm{O}_{3}$ : Posttest for the experimental class

$\mathrm{O}_{4} \quad$ : Posttest for grade control

Variables is determined by the researcher to be studied so that obtained information about it, then pulled the conclusion (Sugiyono, 2012: 60). Independent variable in this research is model of learning PjBL $\left(\mathrm{X}_{1}\right)$ and PBL $\left(\mathrm{X}_{2}\right)$ while the dependent variable (dependent) is the students learning outcomes (Y).

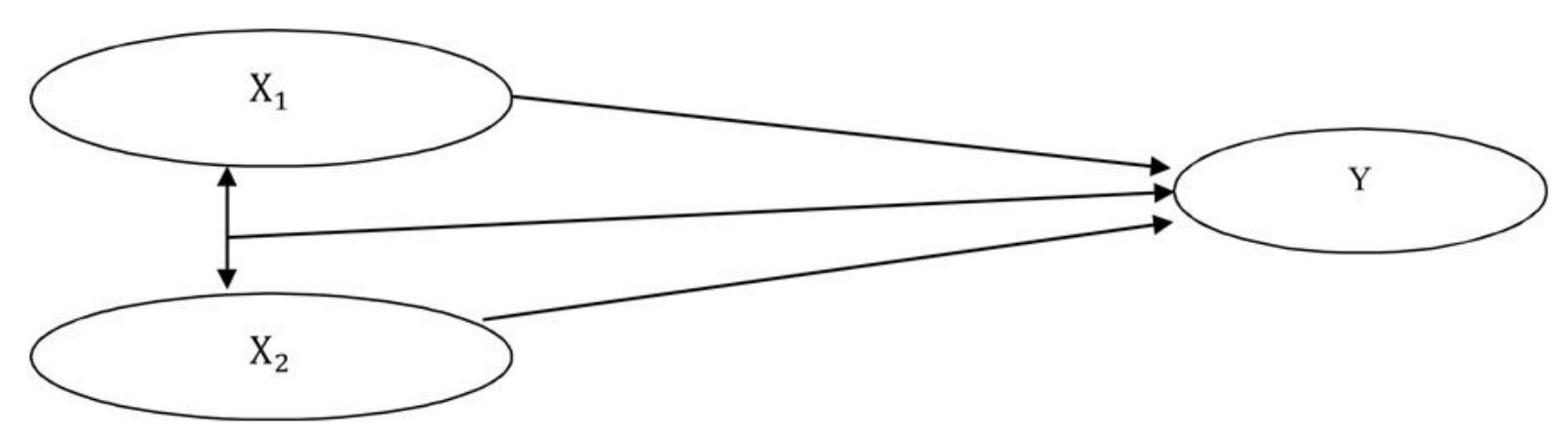

Figure 1. Relation Between Research Variables

The subjects of this study were the students of class X with marketing majors SMK Negeri 1 Pasuruan, with total are 70 students, consisting of students of class $\mathrm{X}$ PM 1 which amounted to 35 students and students of class X PM 2 which amounted to 35 students. The data collected include the data of students 'initial ability (from the value of prates), the students' cognitive domain learning outcomes (from the value of pascates) and the learning outcomes (calculation of post-test values, psychomotor process observation sheets and affective sheets). This study will compare the increase of learning outcomes by reducing the value of learning outcomes with initial ability between the control and experimental classes. The determination of the experimental class is taken from the student's initial ability data.

Testing validity and reliability is a process of testing the items of questions that exist in a problem. To simplify calculate the validity and reliability of data, it can use SPSS version 20. The stages of data analysis is by doing: description of data, test analysis requirements, and test the hypothesis. 


\section{RESULT \& DISCUSSION}

\section{Results}

The lessons learned in class X PM 1 class are acting as control class (PBL learning model) and and X PM 2 experimental class (PjBL learning model), this data is obtained from the result of the students' pretest value. From the test questions that amounted to 50 items that have been done before the validation of content, validity test and test reliability will be taken 25 questions tested for pretest and posttest. The pretest and postest issues are only differentiated on the posttest assignments to be randomly arranged.Description of student learning outcomes of pretest and final ability (postest) is normal and homogeneous.

The result of the students' initial ability showed that the average obtained in the experimental class is 44.4 and the average in the control class is 46.8 and the significance of experimental class is 0.245 and the control class is 0.343 , from the analysis result can be concluded that the initial ability data of experimental class and control class has probability value $>0.05$, then the data is normal whereas it can be seen that the initial ability of experimental class and control class is obtained $p=$ $0.223>0.05$, hence the conclusion of both data is homogeneous. Result of final ability of student showed that normality of cognitive learning result data of experiment class and control class, obtained average in experiment class is 77.03 and average in control class is 75.66 and significance of experiment class is 0.134 and control class is 0.129 . This result can be concluded that cognitive learning result data of experimental class and control class have probability value $>0,05$, then the data is normal while the initial ability of experiment class and control class have $p=0,621>$ 0,05 , hence the conclusion of both data homogeneous.

Based on the result of normality test, homogeneity test, and equality test of mean score on student cognitive learning result data, it can be concluded that the learning result of final ability of students of experiment and control class are same. In other words, the differences in student learning outcomes of the experimental and control classes are due to the treatment and value of the student's cognitive domain. Differences in learning outcomes end-ability and early students not only caused by treatment done at the time of research but on other factors that is in the realm of cognitive.

The affective assessment data of the experimental class and the control class were obtained from the observation of student attitudes and attention during the learning process. Student affective data is obtained by filling in the students' affective assessment observation sheet. During the learning process students have good attention and good enthusiasm as well. Many of the students have great curiosity and also pay attention to the steps on learning even though some students still speak outside the context of learning. This still shows that the quality of learning that took place in the experimental class is good with the average value of 95.2 whereas in general the affective learning outcomes of the students of the control class is good and also on the learning process is quite enthusiastic though still many are late and less attention at Described, the mean affective grade of 92.3 with the highest percentage description is when students help each other and have a polite and systematic way of asking the teacher. This learning students in demand to be 
more active in every learning process so that students have more high motivation in the learning process.

The experimental and control class psychomotor assessment data were obtained by filling out the observation sheets of student process assessments. It is generally seen that the results of the experimental class on work preparation and work attitude are of good value. This shows that the quality of learning that takes place in the experimental class is good. With the average value of psychomotor assessment is 93.7 with description of highest percentage and at work attitude also got mean good value whereas with mean of psychomotor value of control class is 89.9 with description of highest percentage of class in control is in job assessment section time.

Based on the result of the value of affective and psychomotor ability shows the value that does not differ much but has differences in accordance with the criteria of the learning model applied to each class.

The final value calculation is given a greater percentage of the psychomotor process value rating (50\%), the assessment of cognitive observation is given percentage (40\%) and the affective rating is given percentage $(10 \%)$. The results can be seen in the table as follows.

Table 1. Description of Final Assessment Data

\begin{tabular}{|c|c|c|c|c|}
\hline Class & $\begin{array}{l}\text { The lowest } \\
\text { value }\end{array}$ & $\begin{array}{l}\text { Highest } \\
\text { value }\end{array}$ & $\begin{array}{c}\text { The } \\
\text { averagescore }\end{array}$ & $\begin{array}{c}\text { Standa } r \\
\text { deviation }\end{array}$ \\
\hline Control & 80 & 98 & 89.7 & 4.54 \\
\hline Experiment & 84 & 100 & 92.8 & 3.86 \\
\hline
\end{tabular}

From Table 1, there is a difference in final score between the experimental and control classes. This is influenced by the results of cognitive judgments, affective judgments, and psychomotor assessments. The final assessment data of students' learning outcomes is the result of student learning after being combined with the values of the cognitive, affective and psychomotor domains. The highest score on the final grade of the experimental class 100 and the highest end score in the control class is 98, the lowest grade of the experimental class 84 and the control class 80 , and the mean score in the experimental class is 92.8 and the control class is 89.7.

To know the difference between experimental class and control class results using gain score analysis. This initial pretest score after deducting the overall final score (cognitive [postest], affective, psychomotor) will result in gain score as a result of learning online marketing. So it can be more known differences in learning outcomes of the experimental class and control. Of gain score of student learning outcomes that require analysis of normality test, homogeneity and test hypotheses hipotesis. Testing performed using t-test two class. The result of t-test of two-class learning result data can be seen in table 2 as follows. 
Table 2. Results of T-Test of Two Class Data on Student Learning Outcomes

\begin{tabular}{ccccc}
\hline Class & $\overline{\mathrm{X}}$ & $\mathrm{N}$ & $\mathrm{t}_{\text {scores }}$ & tTable \\
\hline Control & 35 & 42.86 & 2,05 & \multirow{2}{*}{1,68} \\
Experiment & 35 & 48.49 & & \\
\hline
\end{tabular}

In Table 2 it can be seen that the gain score of student learning outcomes have $t$ $>t_{\text {table, }}$ so Ho rejected and Ha accepted, so there are differences in learning outcomes between students who are taught by the teaching model PPA (Project Based Learning) with students using the model PBL ( Problem Based Learning). Based on t-test results and the average obtained in Table 2 it can also be stated that the students' learning outcomes of the experimental class are higher than the control class.

\section{Discussion}

Based on the findings of the observer during the process of research implementation of the observation result of Learning Based Learning is in the early stages of learning, the students are still not familiar with the model of Learning Based Learning, this is because the ordinary learning used is the conventional learning model but after the objectives and learning steps are explained students began to get used and followed well and enthusiastically, the results showed that the use of project based learning model has a good influence on the learning process and student learning outcomes are conducive learning conditions and good learning results seen from the observations using the observer sheet has a flat presentation above 90\%. This is supported by Dismawan et al (2014) in his journal which concluded that the application of learning-based project learning model can improve student activity and learning outcomes.

Based on the observer's findings during the process of the implementation of the controlled class student's research, the problem-based learning model initially has not understood how it is applied but after it has been applied to be enthusiastic, the constraint of its application is the problem solving that is determined is still less focused. The results of research conducted that on this learning model students are required to think critically in making decisions to solve problems so that when working on the problem students are not difficult to answer questions. In the implementation of learning, during the student learning process looks active and creative for problem solving provided by the teacher. Observation results have an average score of $80 \%$ indicating good criteria in the learning process. This is supported by Tany et al (2013) in his journal which states that the application of learning problem based learning can improve student learning outcomes such as student orientation in the face of problems, perform analysis and evaluation process to solve the problem well.

The student's initial ability data is derived from the pretest value performed with the same problem between the experimental class and the control class. Data pretest value, in the analysis by using normality test used to know whether the initial state of students data normal or abnormal distribution, homogeneity test is used to determine whether the two classes are homogeneous or not, and t-test is used to determine whether the two classes It has an average initial ability of the experimental class students equal to the average initial ability of the control class 
students or has an average of initial ability that is not the same. The results of the experiments on initial experimental class test and control class have the same initial ability although descriptively The average experiment class has a difference. In the experimental class (X PM 1) has a lower mean value than the control class (X PM 2).

In the initial ability data can be analyzed that students' understanding of online marketing subjects is still very visible from the number of students who have not met the criteria assessed by the school and this also occurs in the two classes studied despite differences.

Assessment of learning outcomes of the cognitive domain is determined by the students' end-ability. The results of cognitive domain learning in the experimental class and control class have differences in terms of value that is in the experimental class has a mean value higher than the control class. Differences in cognitive learning outcomes more visible after the test hypotheses have $t>t$ table, so Ho rejected and Ha accepted. Then it can be concluded that there is a difference between the students' cognitive learning outcomes between classes treated with the PjBL learning model and the classes treated with the PBL model.

Differences in learning outcomes of this cognitive domain have other factors that is in the experimental class students with the treatment of learning model Project Based Learning like the activities applied, in addition to having the character of students who appreciate and would listen so that when the learning process is done with a good understanding and activity with a sense Want to know a high enough while the control class is taught using Problem Based Learning model tends to reluctant to ask, understand or do not understand only some students who want to ask.

Affective spheres are domains related to attitude and value judgments. The experimental results of the affective classes of the experimental and control classes have the same differences although the experimental class is higher than the control class. The average assessment result of both classes is very good because have percentage of assessment of more than 90\%. Although both models of learning equally require students to actively locate and find solutions to problems and projects provided, the activity of the experimental class is higher than that of the control class students. They are very excited when they come up with solutions to problems and then design how to design them in project form, rather than to find solutions to problems without doing projects. Students' activeness and understanding are evident in the learning process by the two applied learning models.

Psychomotor domain is a domain related to skill or ability to act after a person receives a specific learning experience. In this study psychomotor domain that will be assessed that includes assessment of learning outcomes on the observation sheet psychomotor assessed by observer. Learning outcomes psychomotor class experimental class With the control class having the same difference and having good results seen from the average percentage of psychomotor ratings of more than $90 \%$. The experiment class has a value that is superior to the control class. The experimental class has a superior class can be attributed to students' understanding of the material better because the students not only imagine what has been taught but can already arrive at its application. Actually the two classes taught with these two different models love new ways of learning and solving problems. But on the 
understanding of the material and the learning process turned out to be an experimental class by implementing a better and active project. Experiment class students are more enthusiastic to explore the material.

The results showed that the average obtained experiment class is higher than the control class. Based on the above description shows that on the subjects of online marketing more have good results by using the model of learning PjBL (Project Based Learning) in comparison with students using PBL model (Problem Based Learning) which can with a more conducive class circumstances, students are active and Enthusiastic about doing their own project design and good material understanding. This is supported by the fundamental theory mentioned by Sutirman (2013: 46) that the advantages of project based learning are as follows: 1 ) Improving the ability of learners in performing synthesis analysis of a concept, 2) Familiarize students to do the learning process and work systematically , 3) Train students to conduct critical thinking processes in order to solve a real problem, 4) Grow student independence in learning and work, 5) Grow student productivity.

Project-based learning in the experimental class further encourages students to be active in constructing their own knowledge by involving activities such as active inquesting, solving a new way of learning and other activities so that it affects differences in the ability to understand concepts between the experimental class and the control class. While the students are taught using PBL (Problem Based Learning), the students are more passive because they only receive information and look for problems to be solved so that they do not have clear wishes for their practice, the students are not motivated to increase their learning activities in the less Support where learning and problems that occur only limited to the concept alone.

\section{CONCLUSION \& SUGGESTIONS}

\section{Conclusion}

Based on the results and data analysis conducted it can be obtained the following conclusions: (1) In the model of learning PjBL students look more concerned because not only on the boundary of the concept but direct practice using existing facilities in class, other than that how to use in accordance with the ability Students and already familiar to them. In PBL learning model, the students seem to have cooperation and mutual respect for the opinion of friends even though the mastery of the material is still not good because the subjects of online marketing are not limited to the concept only. (2) Based on the results of the analysis of the results of the analysis can be concluded that the experimental class has an average value higher than the control class and the average of cognitive learning outcomes of students of both classes have differences. (3) Based on the result of the research, it is found that the result of learning result of siswakelas higher experiment from control class. Increased learning results obtained from igain score, from the results of data analysis obtained the result that there are differences in the average assessment of student learning outcomes by using the model of learning PjBL (Project Based Learning) and using the model of learning PBL (Problem Based Learning). (4) Based on the research results obtained the final assessment of 
student learning outcomes of higher experimental class of control class. Increased learning results obtained from gain score, from the results of data analysis obtained the result that there are differences in the average assessment of student learning outcomes by using the model of learning PjBL (Project Based Learning) and using the model of learning PBL (Problem Based Learning).

\section{Suggestion}

Based on the results of the research, can be given the following suggestions: (1) For teachers in SMK Negeri 1 Pasuruan especially in Marketing majors can use the model of Project Based Learning (PjBL) to make students active in learning activities on the subjects of Online Marketing because it makes students active and more indepth about the understanding materials that require hands-on practice and guide students to learn independently. (2) For the Principal of SMK Negeri 1 Pasuruan Project Based Learning model should be developed again for different subject matter with the consideration of better classroom management and learning as efficiently as possible, because the learning of Project Based Learning (PjBL) can take a long time and development of Problem Based Learning (PBL) model on the subject matter is also different for the development of instructional innovation as well as to gain the increased competence and knowledge of student learning as well as the quality of better learning. (3) Students in SMK Negeri 1 Pasuruan especially Marketing Department are expected to be more serious in learning process and able to understand the material taught because the teacher is trying hard to do the learning innovation for the more satisfactory learning result. (4) For researchers who will use the learning model of the Project Based Learning (PjBL) and Problem Based Learning (PBL) are advised to use and develop learning methods such as guiding students to focus on subjects taught and make students to learn independently.

\section{REFERENCES}

Ajai, T.J., Imoko I.B. \&O'kwu,E.I. (2013). Comparison of The Learning Effectiveness of Problem Based Learning (PBL) and Conventional Method of Teaching Algebra. Journal of Education and Practice, (Online), 4 (1): 1-6, (http://pakacademicsearch.com/pdffiles/edu/ 413/131135\%20Vol\%204,\%20No\%201\%20(2013), accessed January $20^{\text {th }} 2016$.

Arikunto, S. 2008. Dasar-dasar Evaluasi Pendidikan. Jakarta: Bumi Aksara.

Blandul, V.C. 2015. Innovation in Education-Fundamental Request of Knowledge Society. Social and Behavioral Science. 180: 484-488.

Chan, Z.C.Y. 2017. A Qualitative Study on Using Concept Maps in Problem-Based Learning. Nurse Education in Practice. 24: 70-76. 
Dismawan, M.F., Rapani \& Sulistiasih. 2014 Model Project Based Learning Untuk Meningkatkan Aktivitas Dan Hasil Belajar. Jurnal Pendidikan. (Online), 1-10, (http://download.portalgaruda.org/article.php), diakses 26 Januari 2016.

Ihsan, F. 2011. Dasar-Dasar Kependidikan. Jakarta: PT Asdi Mahasatya.

Johnson, C.S. \& Delawsky, S. 2013. Project-Based Learning and Student Engagement. International Academic Research (Online), 4

$1-11$, (http://www.journals.savap.org.pk/journal.html),

Sugiyono. 2012. Metode Penelitian Pendidikan Pendekatan Kuantitatif, Kualitatif, dan R\&D. Bandung: Alfabeta.

Sugiyono. 2013. Statistika untuk Penelitian. Bandung: Alfabeta.

Sutirman. 2013. Media dan Model Pembelajaran Inovatif. Yogyakarta: Graha Ilmu.

Tany, Y.S., Tri, H.U. 2013. Penerapan Problem Based Learning (PBL) Untuk Meningkatkan Hasil Belajar Siswa di Kelas VII-A SMP Katolik Frateran Celaket 21 Malang. Jurnal Pendidikan Tindakan Kelas, (Online). 